\section{Evaluation of Nine Canadian Retail Consumer Potting Mixes for Growing Container Plants}

\author{
Mary Jane Clark ${ }^{1}$ and Youbin Zheng ${ }^{2}$
}

\begin{abstract}
ADDITIONAL INDEX WORDs. growing substrate, physical property, chemical property, mineral nutrition, leachate, nutrient deficiency

SUMMARY. Commercially available Canadian retail potting mixes were evaluated for physical and chemical properties, as well as for plant performance of petunia ( $\mathrm{Pe}$ tunia $\times$ bybrida 'Storm Pink'), tomato (Solanum lycopersicum 'Better Bush'), and zonal geranium (Pelargonium $\times$ hortorum 'Savannah Red') plants grown outdoors at the Vineland Research and Innovation Center in the Niagara Peninsula in Ontario, Canada. Chemical properties, but no physical properties, resulted in significant correlation with plant growth index, overall appearance, and yield (i.e., flower, fruit, or inflorescence number for petunia, tomato, and zonal geranium, respectively). The performance of all species was best when initial potting mix $\mathrm{pH}$ and electrical conductivity (EC) values were in the ranges of 5.20 to 6.17 and 2.76 to $4.33 \mathrm{mS} \cdot \mathrm{cm}^{-1}$, respectively. The physical properties of the container capacity, total porosity, air space, and bulk density were acceptable for all plants in this study and ranged from $71 \%$ to $80 \%, 78 \%$ to $96 \%, 8 \%$ to $20 \%$, and 0.08 to $0.22 \mathrm{~g} \cdot \mathrm{cm}^{-3}$, respectively. The minimum concentrations of the initial nitrate $\left(\mathrm{NO}_{3}{ }^{-}\right)$, ammonium $\left(\mathrm{NH}_{4}{ }^{+}\right)$, phosphorus $(\mathrm{P})$, and potassium that were acceptable were 104.4, 61.3, 47.9 , and $150.5 \mathrm{ppm}$ for petunia and $96.8,61.3,51.7$, and $143.3 \mathrm{ppm}$ for tomato, respectively. The minimum concentration of $\mathrm{NO}_{3}{ }^{-}$that was acceptable was 66.1 ppm for zonal geranium. Overall appearance at 4, 8, and 10 weeks after transplanting was correlated with initial potting mix $\mathrm{EC}, \mathrm{NO}_{3}{ }^{-}$, and calcium for all species, with $\mathrm{pH}, \mathrm{NH}_{4}{ }^{+}$, and $\mathrm{P}$ for petunia, with $\mathrm{P}$ for tomato at all time points, and with $P$ for zonal geranium after 10 weeks. Although it is difficult to discern how each nutrient impacts plant performance, this study indicated that it is essential to have a balanced and adequate supply of nutrients in consumer potting mixes. The ability of a potting mix to maintain an appropriate $\mathrm{pH}$ for the duration of the growing season may prevent nutrient deficiency symptoms, especially for $\mathrm{pH}$-sensitive species like petunia. This study is the first to provide a benchmark of currently available retail potting mixes for Canadian consumers.
\end{abstract}

$\mathrm{H}$ orticultural crops grown in containers require appropriate growing substrates (i.e., potting mixes) that comprise organic matter components such as sphagnum peat, bark fines, compost, and/ or mineral components such as perlite and vermiculite. Relative to plant requirements, a suitable combination of

Received for publication 20 Aug. 2019. Accepted for publication 15 Nov. 2019.

Published online 17 December 2019

${ }^{1}$ School of Environmental \& Horticultural Studies, Niagara College, 135 Taylor Road, S.S. 4 Niagara-onthe-Lake, ON, LOS 1J0, Canada

${ }^{2}$ School of Environmental Sciences, University of Guelph, 50 Stone Road East, Guelph, ON, NIG $2 \mathrm{Wl}$, Canada

We thank the Scotts Miracle-Gro Company for collaborating and technical support during this work. We also thank Martin Farms Ltd. and Jeffery's Greenhouses Inc. for providing plant material.

Y.Z. is the corresponding author. E-mail: yzheng@ uoguelph.ca.

This is an open access article distributed under the CC BY-NC-ND license (https://creativecommons.org/ licenses/by-nc-nd/4.0/).

https://doi.org/10.21273/HORTTECH04491-19 physical and chemical properties of the potting mix is needed to ensure satisfactory plant performance (Clark and Zheng, 2015; Raviv et al., 2004). Species-specific growing substrates are currently mixed in-house by some greenhouse and nursery growers or customized for growers by professional growing substrate companies. However, many commercially available retail potting mix products provide home gardeners with a generalized ready-touse product. The properties of such retail potting mix products vary with component availability, sustainability initiatives, and environmental factors (Riviere and Caron, 2001). Despite the changing composition of potting mixes, each mix can be characterized by its physical (i.e., bulk density, container capacity, air space, and total porosity) and chemical (i.e., $\mathrm{pH}, \mathrm{EC}$, nutrient concentrations, etc.) characteristics (Wiberg et al., 2005). Optimal pH and EC ranges that produce the majority of horticultural crops in growing substrates have been suggested to be 5.5 to 6.5 and 2.6 to $4.6 \mathrm{mS} \cdot \mathrm{cm}^{-1}$, respectively (Cavins et al., 2000; Reed, 1996). Others have indicated that certain properties [i.e., $\mathrm{pH}$, nitrogen $(\mathrm{N})$ or phosphorus $(\mathrm{P})$ concentrations, soluble salts, water-holding capacity, and/or air space] were correlated with plant growth or ensured appropriate growing conditions by selecting species-specific potting mixes (Allaire et al., 1996; Panj et al., 2014; Pittenger, 1986). A few studies have evaluated plant performance using commercial potting mixes available for general use (Peet et al., 2008; Pittenger, 1986; Wiberg et al., 2006), but no such study has been conducted in Canada.

Currently, a wide variety of potting mixes are commercially available for consumers (e.g., home gardeners) in Canada. In practice, only some commercially available consumer potting mixes perform well. Therefore, benchmarking research is needed to determine which properties characterize top-performing retail potting mixes in Canada. General purpose potting mixes can be used to grow a wide range of plants; however, petunia (Petunia $\times$ bybrida), tomato (Solanum lycopersicum), and zonal geranium (Pelargonium $\times$ hortorum) are among the plants most commonly grown by home gardeners (Froese, 2014). Tomato plants are considered "heavy feeders" and plant

\begin{tabular}{llll}
\hline $\begin{array}{l}\text { Units } \\
\begin{array}{l}\text { To convert U.S. to SI, } \\
\text { multiply by }\end{array}\end{array}$ & U.S. unit & SI unit & $\begin{array}{l}\text { To convert SI to U.S., } \\
\text { multiply by }\end{array}$ \\
\hline 3.7854 & gal & $\mathrm{L}$ & 0.2642 \\
2.54 & inch(es) & $\mathrm{cm}$ & 0.3937 \\
1 & $\mathrm{mmho} / \mathrm{cm}$ & $\mathrm{mS} \cdot \mathrm{cm}^{-1}$ & 1 \\
28.3495 & $\mathrm{oz}$ & $\mathrm{g}$ & 0.0353 \\
7.4892 & $\mathrm{oz} / \mathrm{gal}$ & $\mathrm{g} \cdot \mathrm{L}^{-1}$ & 0.1335 \\
1.7300 & $\mathrm{oz} / \mathrm{inch}^{3}$ & $\mathrm{~g} \cdot \mathrm{cm}^{-3}$ & 0.5780 \\
1 & $\mathrm{ppb}$ & $\mu \mathrm{g} \cdot \mathrm{L}^{-1}$ & 1 \\
1 & $\mathrm{ppm}$ & $\mathrm{mg} \cdot \mathrm{kg}^{-1}$ & 1 \\
$\left({ }^{\circ} \mathrm{F}-32\right) \div 1.8$ & ${ }^{\circ} \mathrm{F}$ & ${ }^{\circ} \mathrm{C}$ & $\left({ }^{\circ} \mathrm{C} \times 1.8\right)+32$
\end{tabular}


performance is primarily determined by plant growth and fruit yield; however, in comparison, petunia and zonal geranium are "medium feeders" with performance determined by plant growth and flower/ inflorescence production (Hebbar et al., 2004; Kang and van Iersel, 2000). The authors are not aware of season-long, container-grown tomato or zonal geranium plant performance studies performed in Canada with a representative survey of retail potting mixes. However, tomato germination and petunia growth research has been presented for commercially available potting mixes in the United States (Peet et al., 2008; Pittenger, 1986; Wiberg et al., 2006). The goal of the current study was to evaluate and provide a benchmark for retail potting mixes that are commonly available to consumers in Canada.

\section{Materials and methods}

PotTing Mixes AND PLANT MATERIAL. Multiple bags for each of nine consumer potting mix products were purchased at popular Canadian retail stores [e.g., Canadian Tire (Toronto, ON, Canada); Home Depot (North York, ON, Canada), etc.; $\mathrm{n}=9$ ] and included well-known potting mix brands such as Answer Garden Products (Abbotsford, BC, Canada), Fafard et Frères Ltée. (Saint-Bonaventure, QC, Canada), Premier Tech (Rivère-du-Loup, QC, Canada), the Scotts Miracle-Gro Co. (Marysville, $\mathrm{OH}$ ), and Sun Gro Horticulture (Agawam, MA). The bag volume for each of the nine potting mixes ranged from 25 to $107 \mathrm{~L}$. To ensure confidentiality, a potting mix reference number was used to differentiate the nine potting mix treatments during the study (i.e., MIX 1 to MIX 9). The initial physical properties of the potting mixes were analyzed using the North Carolina State University porometer method (Fonteno and Harden, 2014) at the University of Guelph (Guelph, ON, Canada). The initial $\mathrm{pH}$ and $\mathrm{EC}$ of the potting mixes were analyzed using a portable $\mathrm{pH}$ and EC meter (PC 300; Oakton Instruments, Vernon Hills, IL) and following the pour-through method (Wright, 1986). The initial chemical properties (Table 1) were analyzed using the saturation extraction method (Warncke, 1986) of an accredited commercial laboratory.

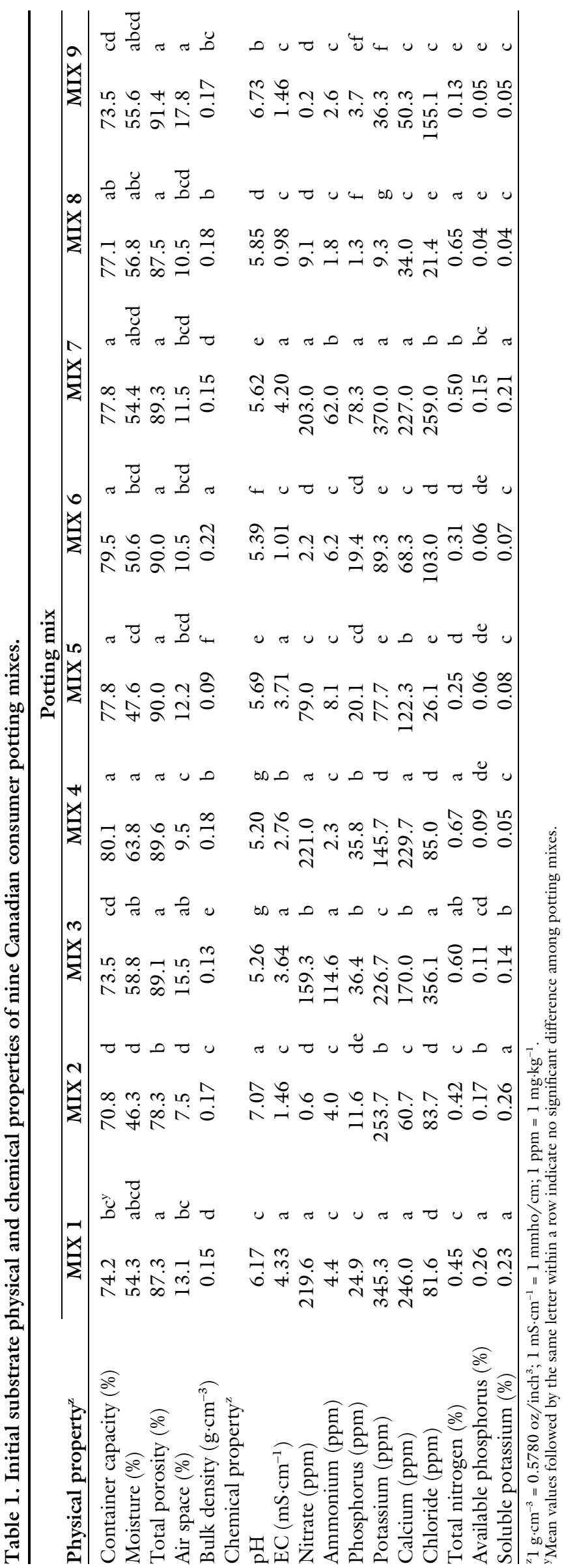


Sample extractions were analyzed by using an inductively coupled plasma spectroscopy (ICP) method for P, potassium $(\mathrm{K})$, and calcium $(\mathrm{Ca})$, and by using a flow injection analysis (FIA) method for chloride $\left(\mathrm{Cl}^{-}\right)$, nitrate $\left(\mathrm{NO}_{3}{ }^{-}\right)$, and ammonium $\left(\mathrm{NH}_{4}{ }^{+}\right)$. Modified total Kjeldahl $\mathrm{N}$ (total $\mathrm{N} \%$ ) was analyzed by grinding a dried sample to pass through a 60-mesh screen and then placing it in a tube with a catalyst tablet and sulfuric acid to digest at $360^{\circ} \mathrm{C}$ for $\approx 75 \mathrm{~min}$. The diluted digested solution was analyzed using the FIA. Available P $(\mathrm{P} \%)$ was analyzed by grinding dried substrate to pass through a 60 -mesh screen and then placing it in a tube with ammonium citrate-ethylenediaminetetraacetic acid (EDTA) extraction solution to digest at $65^{\circ} \mathrm{C}$ for $\approx 60 \mathrm{~min}$. The diluted digested solution was analyzed with an ICP. The soluble $\mathrm{K}(\mathrm{K} \%)$ was analyzed by grinding a dried sample to pass through a 60-mesh screen and then placing it in a tube with ammonium oxalate extraction solution to digest at $100{ }^{\circ} \mathrm{C}$ for $\approx 30 \mathrm{~min}$. The diluted digested solution was analyzed using an ICP.

Before planting on 14 May 2014 , contents of multiple bags of each potting mix were combined and thoroughly mixed to reduce lot differences or differences among bags and moistened with municipalsourced tap water $(\mathrm{pH} 7.93$; EC, $0.36 \mathrm{mS} \cdot \mathrm{cm}^{-1} ; 100 \mu \mathrm{g} \cdot \mathrm{L}^{-1}$ bicarbonate alkalinity). Containers were filled with moistened potting mix and tapped three times on a level surface; then, the substrate volume was adjusted to $\approx 2 \mathrm{~cm}$ below the container rim to ensure consistency among containers. A single 8-week-old tomato plant from an $8-\mathrm{cm}$-diameter square container was transplanted into $21.0 \mathrm{~L}$ of potting mix in a 39.7 $\mathrm{cm}$-diameter plastic container. Either two petunia plants from $3-\mathrm{cm}$-diameter plugs or one zonal geranium plant from $10-\mathrm{cm}$-diameter round containers were transplanted to 8.5 L of potting mix in $32.4-\mathrm{cm}$-diameter plastic containers.

EXPERIMENTAL DESIgN. All containers were placed outdoors adjacent to a research greenhouse at the Vineland Research and Innovation Center (Vineland Station, ON, Canada) on a well-drained black fabric-covered gravel surface in a randomized block design, grouped by species. The five replications of each potting mix treatment were randomly arranged with equal spacing among pots. Individuals within groups were re-randomized from time to time to reduce location error.

Plant growth AND MEASUREMENTS. Using a soil moisture meter (WET sensor; Delta-T Devices, Cambridge, UK), the percent moisture of the potting mix for representative containers of each species was evaluated daily using the organic substrate setting. If the moisture reading was $<20 \% \pm 5 \%$, then containers were watered with tap water by hand with a hose equipped with an electronic water meter (Gardena Canada, Brampton, ON, Canada) to achieve a leaching fraction of $\approx 20 \%$ (3.6 L for tomato and $1.6 \mathrm{~L}$ for petunia and geranium plants, on average). For the nine potting mixes, watering frequency ranged from 1.1 to $2.4,1.2$ to 2.7 , and 1.1 to 1.5 times per week, and the volume of water added ranged from 1.7 to $4.0,3.2$ to 11.5 , and 1.6 to $2.5 \mathrm{~L}$ per week, for petunia, tomato, and zonal geranium plants, respectively. No fertilizer was applied to plants during the study.

Plant growth index was evaluated biweekly by measuring plant height and plant width in two perpendicular directions to calculate growth index $\left[\left(\right.\right.$ height $\times$ width $_{1} \times$ width $\left._{2}\right) \div 300$ ], as outlined by Ruter (1992). Growing substrate $\mathrm{pH}$ and EC were measured for all plants at 4, 7 , and 10 weeks after transplanting (WAT) using the pour-through method (Wright, 1986). Petunia flowers and zonal geranium inflorescences were counted by removing fully opened flowers weekly. Visual nutrient deficiency symptoms were noted for individual plants for the duration of the study. At six time points, the overall appearance of all plants was ranked from 1 (worst) to 5 (best), relative to plants of the same species. The plant characteristics used to develop overall appearance values were foliage density and color, flowering, plant vigor, branching, and fruit production for tomato plants. The existence of weeds per container was noted, and weeds were removed from containers weekly. During and after week 7 , tomato plant branches were loosely attached to bamboo stakes, as needed, to support the fruit weight. After 10 weeks of growth, the number and fresh weight of ripe and unripe tomato fruit (yield) were evaluated. Shoots of all plants were cut at the soil surface and dried in paper bags in an air-forced model drying oven at $70{ }^{\circ} \mathrm{C}$ until a constant weight was achieved. Water use efficiency (WUE) was calculated as the shoot dry weight $\div$ total volume of water applied per species.

Statistical analysis. All data sets were analyzed using GraphPad Prism software (version 5.03; GraphPad Software, La Jolla, CA). A twoway repeated-measures analysis of variance (ANOVA) with a Bonferroni post-test was used to evaluate differences among treatments and time points for growth index, overall appearance, leachate $\mathrm{EC}$, and $\mathrm{pH}$ among potting mix treatments. Overall appearance rankings at all time points were combined and analyzed using a one-way ANOVA, with differences among means determined according to Tukey's multiple comparison test. In addition, a one-way ANOVA was conducted for the initial physical and chemical properties, shoot dry weight, growth index, yield, number of weeding events, and WUE, with differences among means determined according to Tukey's multiple comparison test. Pearson correlation coefficients (r) were calculated to compare the overall appearance, growth index, shoot dry weight, and yield to potting mix physical and chemical properties. In addition, Pearson correlation coefficients were calculated to compare the WUE to the container capacity and initial chemical properties. Regression analyses were used to relate yield to chemical properties after 10 weeks of growth and to estimate regression parameters for the best-fit regression model (linear or quadratic). Using significant regression equations, acceptable ranges were calculated as $\pm 90 \%$ of the maximum point on the quadratic curve. All data were evaluated using a significance level of $P<$ 0.05 .

\section{Results}

Overall appearance. Plants with the best overall appearance had many flowers or inflorescences, a large plant size, few or no nutrient deficiency symptoms, and an appealing shape. A high overall appearance was observed for MIX 3, MIX 4, and MIX 7 for petunia; for MIX 1, MIX 3, MIX 4, and MIX 7 for tomato; and for 
MIX 1, MIX 4, MIX 5, and MIX 7 for zonal geranium (Table 2).

Overall appearances at 4,8 , and 10 WAT were correlated with the initial potting mix $\mathrm{EC}, \mathrm{NO}_{3}^{-}$, and Ca for petunia $(\mathrm{r}=0.73,0.79,0.83$; $\mathrm{r}=0.80,0.89,0.86 ; \mathrm{r}=0.75,0.84$, $0.82)$, tomato $(\mathrm{r}=0.83,0.78,0.83$; $\mathrm{r}=0.91,0.86,0.86 ; \mathrm{r}=0.90,0.81$, $0.82)$, and zonal geranium $(\mathrm{r}=0.84$, $0.75,0.74 ; \mathrm{r}=0.72,0.95,0.94 ; \mathrm{r}=$ $0.72,0.92,0.91)$, respectively. Initial potting mix concentrations of $\mathrm{NH}_{4}{ }^{+}$ and $\mathrm{P}$ were correlated with the overall appearance of petunia at 4,8 , and 10 WAT $(\mathrm{r}=0.73,0.70,0.72 ; \mathrm{r}=0.77$. $0.77,0.74)$, respectively. In addition, the initial potting mix $\mathrm{pH}$ was negatively correlated with the overall appearance of petunia at 4 and 8 WAT $(\mathrm{r}=-0.75$ and -0.69 , respectively $)$. The initial $\mathrm{P}$ of the potting mix was also correlated with the overall appearance of tomato at 4,8 and 10 WAT $(\mathrm{r}=0.84,0.76$, and 0.74 , respectively), as was $\mathrm{NH}_{4}{ }^{+}$at 8 and 10 WAT $(\mathrm{r}=0.71$ and 0.72 , respectively). The initial $\mathrm{P}$ influenced the overall appearance of zonal geranium 10 weeks after planting $(\mathrm{r}=0.73)$. Plants grown in MIX 2 and MIX 9 had the worst overall appearance among all species. No potting mix physical property was correlated with the overall appearance of any species at any time point.

Plant growth. At 10 WAT, the greatest or among the greatest shoot dry weights were observed for petunia and tomato plants in MIX 3 and MIX
7 and for zonal geranium plants in MIX 1 and MIX 4 (Table 2).

The greatest or among the greatest growth indices for all species were observed for MIX 3 and MIX 7 (Table $2)$. Conversely, unacceptable plant growth was observed for all species with MIX 2, MIX 6, MIX 8, and MIX 9. Considering the chemical properties, the initial EC, $\mathrm{NO}_{3}{ }^{-}, \mathrm{P}$, and $\mathrm{Ca}$ were each positively correlated with the final growth index for petunia $(\mathrm{r}=$ $0.80,0.84,0.82$, and 0.84 , respectively), tomato $(\mathrm{r}=0.89,0.91,0.75$, and 0.89 , respectively), and zonal geranium $(\mathrm{r}=0.90,0.93,0.71$, and 0.92 , respectively), whereas $\mathrm{NH}_{4}{ }^{+}$ and $\mathrm{K}$ were correlated with the petunia final growth index $(\mathrm{r}=0.7 \mathrm{l}$ and 0.74 , respectively). In addition, when

Table 2. Plant performance and water use efficiency of petunia, tomato, and zonal geranium grown in nine consumer potting mixes 10 weeks after transplanting.

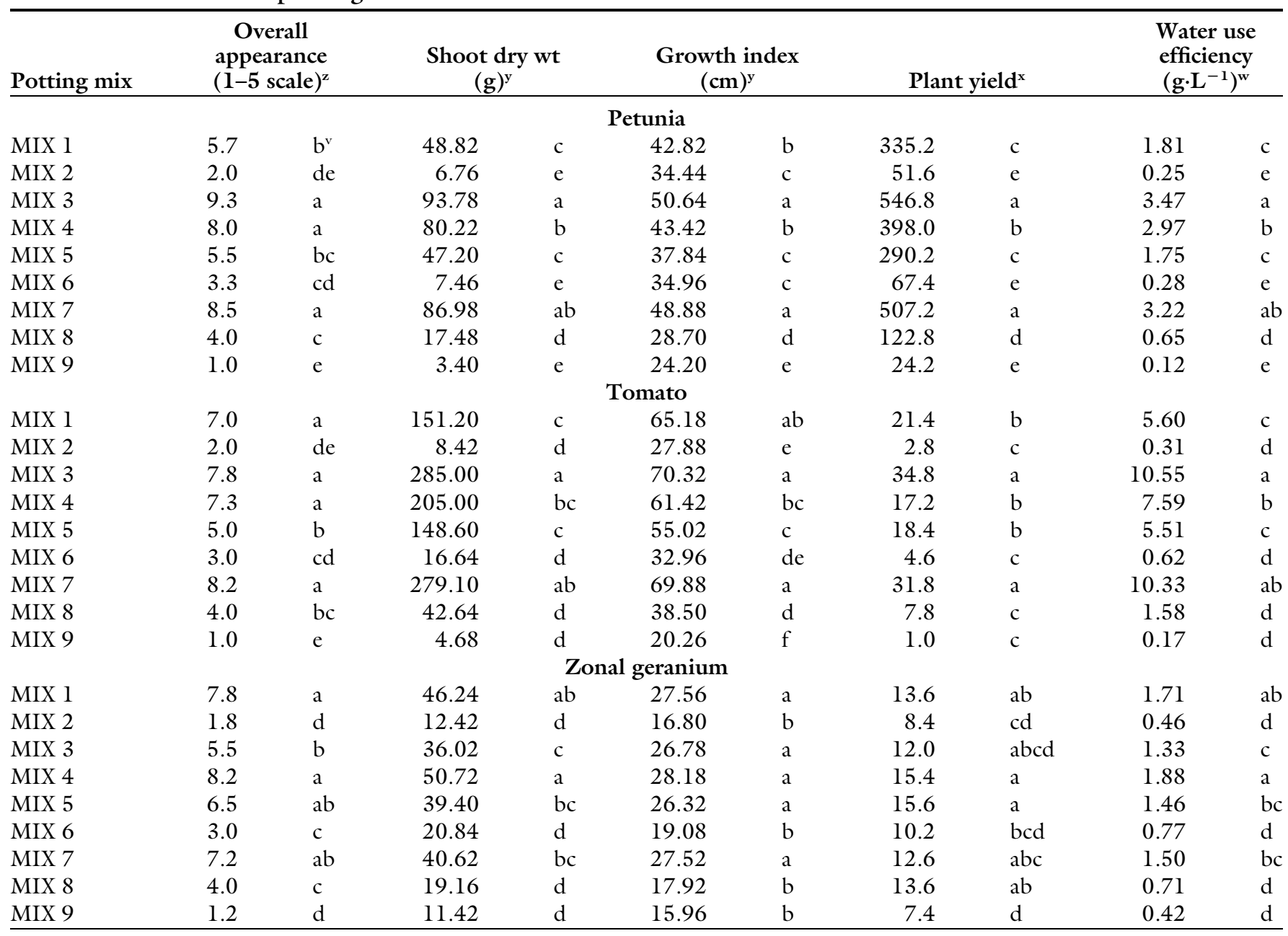

${ }^{\mathrm{z}}$ Visual ranking using a scale of 1 to 5 based on foliage density and color, flowering, plant vigor, branching, and fruit production for tomato. Data are grouped means evaluated biweekly over 10 weeks per potting mix.

${ }^{\mathrm{y}} \mathrm{l} \mathrm{g}=0.0353 \mathrm{oz} ; 1 \mathrm{~cm}=0.3937$ inch.

${ }^{\mathrm{x}}$ Total cumulative numbers of flowers and inflorescences for petunia and geranium, respectively, and total harvested fruit (ripe and unripe) number 10 weeks after transplanting for tomato.

wWater use efficiency (grams of dry shoot tissue per liter of irrigation water applied); $1 \mathrm{~g} \cdot \mathrm{L}^{-1}=0.1335 \mathrm{oz} / \mathrm{gal}$.

${ }^{v}$ Mean values in the same column for the same plant species followed by the same letter indicate no significant difference among potting mixes. 
$\mathrm{pH}$ and EC measured initially and at 4 and 7 WAT were compared with plant growth at 4 and 10 WAT (Fig. 1), additional correlation relationships were established. In general, petunia was influenced more than tomato or zonal geranium by potting mix $\mathrm{pH}$ during the study. At 4 WAT, the petunia growth index was negatively correlated with the initial $\mathrm{pH}$ and $\mathrm{pH}$ measured 4 and 7 WAT $(\mathrm{r}=-0.85$, -0.89 , and -0.82 , respectively), and the final petunia growth was negatively correlated with $\mathrm{pH}$ at 4 WAT $(\mathrm{r}=-0.72)$. In addition, the tomato growth index at 4 WAT was negatively correlated with the initial $\mathrm{pH}$ $(\mathrm{r}=-0.70)$. However, more correlations were observed for potting mix EC than for $\mathrm{pH}$. Specifically, the final growth index was positively correlated with EC initially and at 4 WAT for tomato $(\mathrm{r}=0.89$ and 0.80$)$ and zonal geranium $(\mathrm{r}=0.90$ and 0.78$)$, as well as for petunia initially and at 4 and 7 WAT $(\mathrm{r}=0.80,0.82$, and $0.75)$. In addition, growth index at 4 WAT was positively correlated with the initial potting mix EC for tomato $(\mathrm{r}=0.76)$ and zonal geranium $(\mathrm{r}=$ 0.74).

Plant Yield. The total flower number for petunia, fruit number for tomato, and inflorescence number for zonal geranium defined plant yield in the current study. Total petunia and tomato yields were high 10 weeks after planting in MIX 3 and MIX 7. However, a high zonal geranium yield was observed in MIX 1 , MIX 4, MIX 5, and MIX 8 (Table 2).

Initial $\mathrm{EC}, \mathrm{NO}_{3}{ }^{-}, \mathrm{NH}_{4}{ }^{+}, \mathrm{P}$, and $\mathrm{Ca}$ of the potting mixes were positively correlated at 10 WAT with petunia flower number $(\mathrm{r}=0.85$, $0.88,0.73,0.80$, and 0.84 , respectively), tomato number $(\mathrm{r}=0.87$, $0.81,0.79,0.79$, and 0.78 , respectively), and tomato fruit fresh weight $(\mathrm{r}=0.93,0.90,0.68,0.77$, and 0.88 ). Tomato fruit fresh weight was also correlated with the initial $\mathrm{K}$ of the potting mixes $(\mathrm{r}=0.70)$. Zonal geranium yield was not correlated with any chemical property, and no physical property was correlated with plant yield measurements for any species.

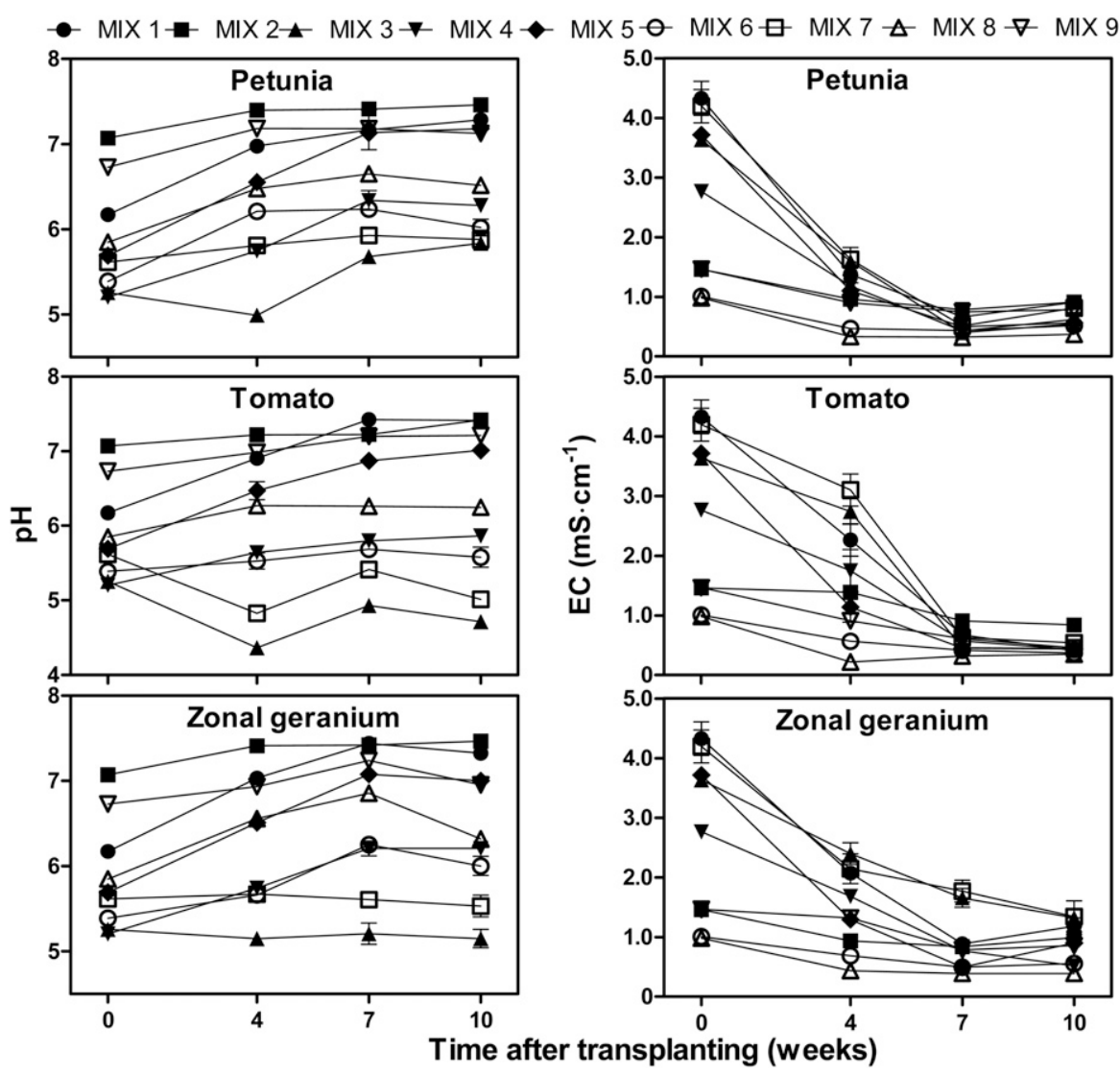

Fig. 1. Mean $( \pm \mathrm{SE}) \mathrm{pH}$ and electrical conductivity (EC) of nine unfertilized commercial consumer potting mixes at planting and at 4,7 , and 10 weeks of petunia, tomato, and zonal geranium growth $(\mathrm{n}=5) ; 1 \mathrm{mS} \cdot \mathrm{cm}^{-1}=1 \mathrm{mmho} / \mathrm{cm}$.

A regression analysis of plant yield and initial chemical properties is illustrated in Fig. 2. A negative linear relationship was observed between plant yield for all three species and the initial potting mix $\mathrm{pH}$. Although a positive linear relationship was observed between the tomato and zonal geranium yield and initial EC, a quadratic relationship indicated that the acceptable range for the initial potting mix EC for petunia yield was 3.3 to $5.6 \mathrm{mS} \cdot \mathrm{cm}^{-1}$. Based on plant yield, the minimum acceptable limit of the initial $\mathrm{NO}_{3}{ }^{-}$in potting mixes was $104.4 \mathrm{ppm}$ for petunia, $96.8 \mathrm{ppm}$ for tomato, and $66.1 \mathrm{ppm}$ for zonal geranium (Fig. $2)$. The minimum acceptable initial $\mathrm{NH}_{4}{ }^{+}, \mathrm{P}$, and $\mathrm{Ca}$ concentrations were $61.3,47.9$, and 150.5 ppm for petunia and 61.3, 51.7, and $143.3 \mathrm{ppm}$ for tomato, respectively. Petunia and tomato yields increased linearly with the initial $\mathrm{K}$ concentration. The response of the zonal geranium inflorescence number to the initial $\mathrm{NH}_{4}{ }^{+}$, $\mathrm{P}$, and $\mathrm{K}$ concentrations was not significant, but the inflorescence number increased linearly in relation to the Ca concentration.

NuTRIENT DEFICIENCY SYMPTOMS. Interveinal chlorosis was observed for all three species and developed on young petunia leaves by 5 WAT for MIX 1 and MIX 5 and by 10 WAT for MIX 2 and MIX 7. In addition, interveinal chlorosis was observed on young tomato leaves by 10 WAT for MIX 1, MIX 3, MIX 6, and MIX 7 and on young zonal geranium leaves by 10 WAT for MIX 1, MIX 4, and MIX 5. All three species also developed yellow and brown mature leaves and leaf tips by 10 WAT when grown in MIX 8, on petunia plants grown in MIX 9, on tomato plants grown in MIX 1, MIX 2, MIX 3, MIX 4, MIX 5 , MIX 6. and MIX 7, and on zonal geranium plants grown in MIX 3, MIX 5, and MIX 6. In addition, tomato leaves were yellow by 5 WAT for MIX 6 and MIX 9. Light green leaves were observed on petunia plants by 5 WAT for MIX 2 and MIX 9 and by 10 WAT for MIX 1 , MIX 4, MIX 5, and MIX 6; tomato leaves were light green by 5 WAT on plants grown in most potting mixes and by 10 WAT for the remainder (i.e., MIX 2, MIX 5, and MIX 9). Zonal geranium leaves were red, pink, and yellow by 5 WAT for MIX 6 and 

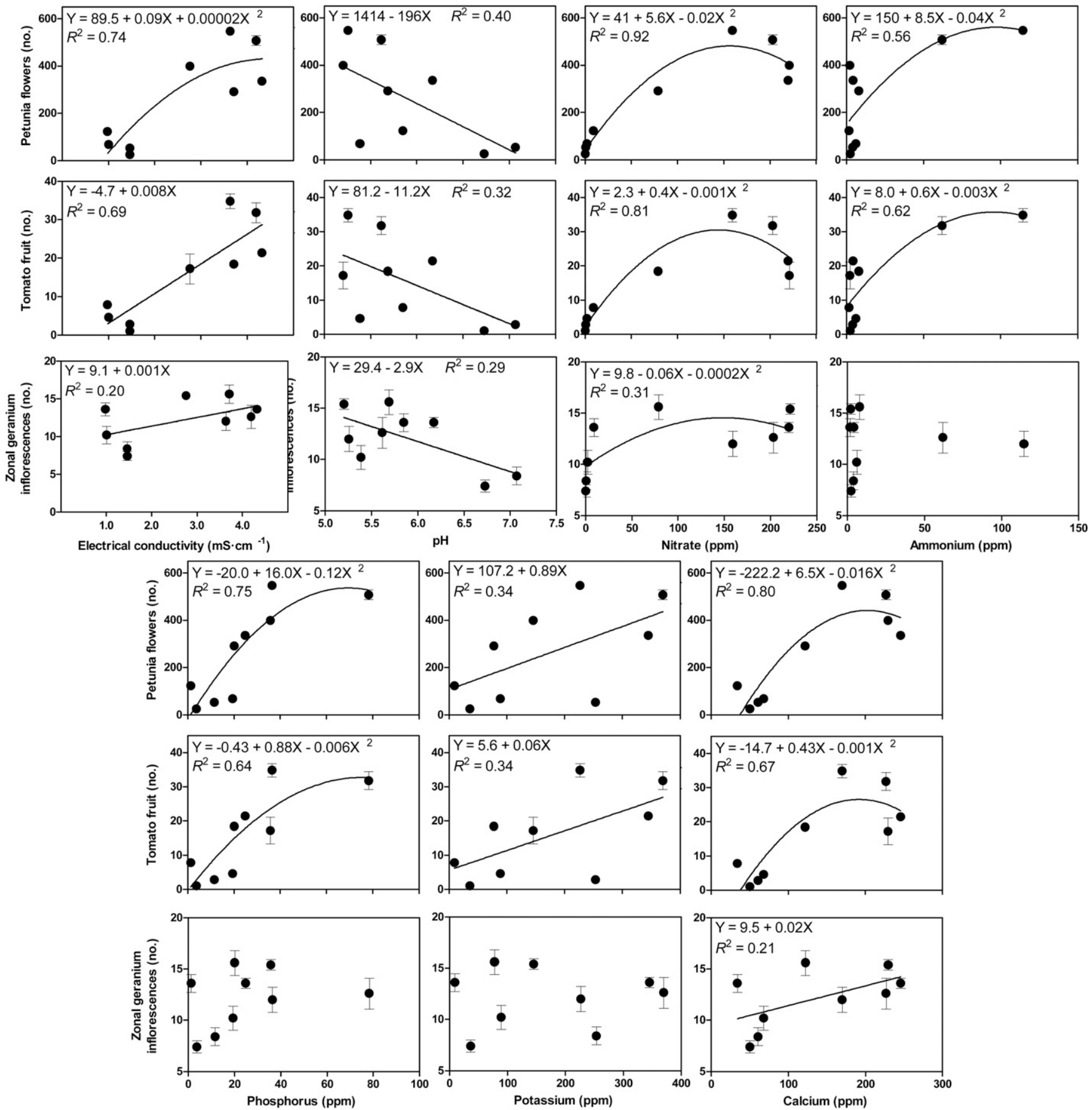

Fig. 2. Regression analysis of petunia, tomato, and zonal geranium plant yields after 10 weeks of growth compared to the initial growing substrate chemical properties for nine unfertilized commercial consumer potting mixes. Data are means \pm SE $(n=5)$. When the effect of the chemical property was significant $(P<0.05)$, equations and lines indicate the calculated regression; otherwise, no lines are shown; $1 \mathrm{mS} \cdot \mathrm{cm}^{-1}=1 \mathrm{mmho} / \mathrm{cm}$ and $1 \mathrm{ppm}=1 \mathrm{mg} \cdot \mathrm{kg}^{-1}$.

by 10 WAT for MIX 2, MIX 8 , and MIX 9 ; tomato leaves were a purple by 5 WAT for MIX 2, MIX 6, and MIX 9 and by 10 WAT for the remainder of potting mixes. Plants showing these color-indicating nutrient deficiency symptoms produced fewer flowers or inflorescences, and nutrient-deficient petunia plants produced smaller, sometimes lighter colored, flowers than plants without nutrient deficiency symptoms. Tomato plants with severe nutrient deficiency symptoms appeared to stop flowering sooner in the study and aborted more flowers than plants with few nutrient deficiency symptoms. However, tomato plants with severe nutrient deficiency symptoms produced fewer mature fruit and consequently showed fewer blossom end rot symptoms than plants with few nutrient deficiency symptoms.

PotTing Mix PHYSical AND CHEMICAL PROPERTIES. The nine commercially available potting mixes in the current study differed in their initial physical and chemical properties 
(Table 1). Only four potting mixes (MIX 1, MIX 3, MIX 5, and MIX 7) had an initial pH slightly below or within the range appropriate for plant growth in growing substrates (i.e., 5.5 to 6.5). MIX 1, MIX 3, MIX 5, and MIX 7 also had appropriate initial EC values (2.6 to 4.6 $\left.\mathrm{mS} \cdot \mathrm{cm}^{-1}\right)$. At 10 WAT, the $\mathrm{pH}$ values of MIX 3, MIX 4, MIX 6, MIX 7, and MIX 8 were slightly below or within the appropriate range for plant growth, whereas the $\mathrm{pH}$ values for most other mixes, especially MIX 2 and MIX 9, were above the appropriate range for plant growth. In general, for each potting mix, the $\mathrm{pH}$ was constant and did not drastically change over the course of the study. The EC of all potting mixes at 7 WAT was below the range appropriate for plant growth (i.e., $<2.6 \mathrm{mS} \cdot \mathrm{cm}^{-1}$ ) (Fig. 1). Overall, the performance of all species was best when the initial potting mix $\mathrm{pH}$ and $\mathrm{EC}$ values were in the ranges of 5.20 to 6.17 and 2.76 to $4.33 \mathrm{mS} \cdot \mathrm{cm}^{-1}$, respectively. The range of values for physical properties were acceptable in this study for container capacity (71\% to $80 \%)$, total porosity $(78 \%$ to $96 \%)$, air space $(7 \%$ to $20 \%)$, and bulk density $\left(0.08\right.$ to $\left.0.22 \mathrm{~g} \cdot \mathrm{cm}^{-3}\right)$.

WeEDs. The visual quality of the planted container was negatively impacted by weed growth. The greatest prevalence of weed growth occurred for MIX 1 and MIX 8, which, on average, required weeding on three and two occasions during the study, respectively $(\mathrm{n}=$ 15). Conversely, MIX 4 and MIX 5 required the least amount of weeding during the study.

WATER USE EFFICIENCY. The WUE was calculated as the volume of water per gram of dry shoot tissue; it was greatest for MIX 3 and MIX 7 for petunia and tomato and least for MIX 2, MIX 6, MIX 8, and MIX 9 for all species (Table 2). The zonal geranium WUE was greatest for MIX 1 and MIX 4. Correlations were observed between WUE and the initial potting mix $\mathrm{EC}, \mathrm{NO}_{3}^{-}$, and Ca for petunia $(\mathrm{r}=0.80,0.88$, and $0.84)$, tomato $(r=0.84,0.87$, and $0.83)$, and zonal geranium $(\mathrm{r}=0.83$, 0.93 , and 0.92$)$, respectively. The WUE was also correlated with $\mathrm{NH}_{4}{ }^{+}$ and $\mathrm{P}$ for petunia $(\mathrm{r}=0.70$ and 0.80$)$ and tomato $(\mathrm{r}=0.74$ and 0.82$)$, respectively. The container capacity of potting mixes was not correlated with WUE for any species.

\section{Discussion}

The nine potting mixes included in this study are all commonly available at Canadian retail stores. To benchmark the quality of Canadian commercial consumer potting mixes, this study determined that chemical properties were the critical parameters for plant performance in a consumer potting mix. Because individual physical properties were not correlated with plant performance, the physical properties of all of the mixes tested were within acceptable ranges for plant growth under appropriate irrigation conditions (Bilderback, 1999; Raviv et al., 2004). Correlations between the plant growth index and EC level indicated that consistent plant available nutrients between transplanting and 4 WAT had a significant influence on plant performance in containers. Specifically, the potting mixes (i.e., MIX 3 and MIX 7) that had initial EC, initial $\mathrm{pH}$, and final $\mathrm{pH}$ values within or slightly lower than the recommended optimal ranges for plant growth (i.e., $\mathrm{pH} 5.5$ to 6.5 and EC 2.6 to $4.6 \mathrm{mS} \cdot \mathrm{cm}^{-1}$, respectively) (Cavins et al., 2000; Reed, 1996) resulted in a high growth index for all species as well as high shoot dry weight and yield. In general, the best plant performance was observed for plants grown in potting mixes with a low initial $\mathrm{pH}$ and high EC (i.e., 4.33 and $\left.4.2 \mathrm{mS} \cdot \mathrm{cm}^{-1}\right)$. Conversely, MIX 2 and MIX 9, which had pH levels higher than the acceptable range (i.e., 6.5) and low initial EC levels, resulted in the poorest plant performance, which clearly showed the importance of appropriate $\mathrm{pH}$ and EC levels for consumer potting mixes. Significant quadratic regression relationships suggested the minimum concentrations of the initial $\mathrm{NO}_{3}{ }^{-}, \mathrm{NH}_{4}{ }^{+}, \mathrm{P}$ and $\mathrm{Ca}$ for petunia (i.e., 104.4, 61.3, 47.9, and 150.5 ppm, respectively) and tomato (i.e., 96.8, 61.3, 51.7, and $143.3 \mathrm{ppm}$, respectively) and of $\mathrm{NO}_{3}{ }^{-}$for zonal geranium (i.e., $66.1 \mathrm{ppm}$ ). In addition, positive linear relationships were observed between $\mathrm{K}$ and petunia and tomato yields as well as Ca and zonal geranium yield. These relationships may explain the high performance of each species in the individual potting mixes that have initial nutrient contents that most closely match their nutrient preferences. In particular, petunia and tomato performed well, with high overall appearance, growth index, and yield with MIX 3 and MIX 7, which provided acceptable nutrient concentrations. In addition, zonal geranium performed well with MIX 1 and MIX 4, which also had appropriate $\mathrm{NO}_{3}{ }^{-}$and $\mathrm{Ca}$ concentrations. However, these two mixes had low $\mathrm{NH}_{4}{ }^{+}$concentrations (i.e., 4.4 and $2.3 \mathrm{ppm}$ ) that were below the acceptable concentrations for petunia and tomato (i.e., <61.3 ppm). Although it is difficult to discern how each nutrient impacts plant performance, this study indicated that it is essential to have a balanced and adequate supply of nutrients in commercial consumer potting mixes. The majority of potting mixes evaluated in the current study required additional fertilization after week 4 to ensure that the EC was within the appropriate range for plant growth. Therefore, Canadian consumers will need to apply additional fertilizer when using these potting mixes to ensure acceptable plant growth and performance throughout the growing season.

In addition to influencing plant growth and yield, potting mix $\mathrm{pH}$ may also have a role in preventing nutrient deficiencies, especially for $\mathrm{pH}$-sensitive species like petunia. High $\mathrm{pH}$ root zone environments can reduce the availability of key nutrients such as iron or magnesium, leading to the development of symptoms such as interveinal chlorosis (Marschner, 1995). Such symptoms were observed for petunia at 5 WAT for MIX 1 and MIX 5, as well as at 10 WAT for MIX 2, all of which had high $\mathrm{pH}$ levels (i.e., >6.5). However, even under conditions of low nutrient concentrations, as measured by EC in the current study, no interveinal chlorosis was observed for petunia in MIX 3, which maintained a consistently low $\mathrm{pH}$ for the duration of the study. Therefore, by ensuring that potting mixes have long-lasting and appropriate $\mathrm{pH}$ levels, nutrient deficiency symptoms could be prevented for $\mathrm{pH}$-sensitive species. Further research is needed to evaluate tissue nutrient concentrations under low EC levels to more clearly identify $\mathrm{pH}$-induced nutrient deficiencies in species such as petunia. 
Water restrictions are often in effect during the growing season, and ornamental plants with the ability to grow well with less frequent watering or lower watering volumes are desirable. Potting mixes can influence the frequency and volume of water needed for plant growth, and multiple products that allow the ability to reduce the need for frequent water application are available to consumers. Although they did not differ in WUE for any species, MIX 3 and MIX 7 differed in watering frequency, and they had among the largest growth index values for all species. For petunia and tomato, MIX 3 required more frequent water applications than MIX 7; however, for zonal geranium, the opposite was observed. Although MIX 7 had a greater container capacity than MIX 3, neither irrigation volume nor frequency was correlated with the potting mix container capacity. The consumer potting mixes in the current study had a container capacity greater (i.e., $71 \%$ to $80 \%$ ) than the recommended range for commercial production (i.e., $45 \%$ to $65 \%$ ) (Yeager et al., 2007); however, plant performance was not negatively affected. Likely, when plants reach a large size, the container capacity did not impact irrigation frequency or volume as much as that observed for small plants. Therefore, the irrigation frequency and volume differences in the current study were likely influenced by plant growth and not just the potting mix container capacity. Although many studies reported the response of plant growth to irrigation regimes (Kirda et al., 2004; Scheiber and Beeson, 2006), further research is needed to determine how both plant growth and container capacity influence irrigation requirements when watering is determined by threshold volumetric water content levels.

This is the first study to the authors' knowledge to provide a benchmark for consumer potting mix products in Canada. An ideal potting mix can be characterized by an appropriate nutrient composition for speciesspecific growth, $\mathrm{EC}$ and $\mathrm{pH}$ values maintained within the appropriate range for plant growth during the growing season, and the ability to reduce watering frequency while ensuring the desired plant performance. To aid consumers in making informed purchasing decisions, including such detailed characteristics with fertilization recommendations should be implemented because it would be beneficial as a standard part of potting mix labeling.

\section{Literature cited}

Allaire, S.E., J. Caron, I. Duchesne, L.-E. Parent, and J.-A. Rioux. 1996. Air-filled porosity, gas relative diffusivity, and tortuosity: Indices of Prunus x cistena sp. growth in peat substrates. J. Amer. Soc. Hort. Sci. 121:236-242.

Bilderback, T. 1999. Potting mix choices and recommendations. Proc. North Carolina State Nursery Short Course 1:1115.

Cavins, T.J., B.E. Whipker, W.C. Fonteno, B. Harden, I. McCall, and J.L. Gibson. 2000. Monitoring and managing $\mathrm{pH}$ and EC using the pourthru extraction method. 30 Mar. 2015. <http://www.ces. ncsu.edu/depts/hort/floriculture/hils/ HIL590.pdf>.

Clark, M.J. and Y. Zheng. 2015. Use of species-specific controlled-release fertilizer rates to manage growth and quality of container nursery crops. HortTechnology 25:370-379.

Fonteno, W.C. and C.T. Harden. 2014. Procedures for determining physical properties of horticultural substrates using the NCSU porometer. Horticultural Substrates Library, Dept. Hort. Sci., North Carolina State Univ., Raleigh.

Froese, C. 2014. Gardens give sense of serenity. 18 Mar. 2015. <http://www. producer.com $/ 2014 / 07 /$ gardensgive-sense-of-serenity $/>$.

Hebbar, S.S., B.K. Ramachandrappa, H.V. Nanjappa, and M. Prabhakar. 2004. Studies on NPK drip fertigation in field grown tomato (Lycopersicon esculentum Mill.). Eur. J. Agron. 21:117-127.

Kang, J.-G. and M.W. van Iersel. 2000. Interactions of temperature and fertilizer concentration affect growth of petunia and geranium. HortScience 35:457 (abstr.).

Kirda, C., M. Cetin, Y. Dasgan, S. Topcu, H. Kaman, B. Ekici, M.R. Derici, and A.I. Ozguven. 2004. Yield response of greenhouse grown tomato to partial root drying and conventional deficit irrigation. Agr. Water Manage. 69:191-201.
Marschner, H. 1995. Mineral nutrition of higher plants. 2nd ed. Academic Press, London, UK.

Panj, F.G., S. Kumari, and P.B. Parmar. 2014. Effect of growing media properties and its correlation study in gerbera production. Bioscan 9:79-83.

Peet, M.M., E.S. Larrea, and C. Harlow. 2008. Tomato seed germination in organic mixes: Role of EC and mix components. Acta Hort. 797:393-398.

Pittenger, D.R. 1986. Potting soil label information is inadequate. Calif. Agr. 40(11):6-8.

Raviv, M., R. Wallach, and T.J. Blom. 2004. The effect of physical properties of soilless media on plant performance - A review. Acta Hort. 644:251-259.

Riviere, L.-M. and J. Caron. 2001. Research on substrates: State of the art and need for the coming 10 years. Acta Hort. 548:29-41.

Reed, D.W. 1996. A grower's guide to water, media, and nutrition for greenhouse crops. Ball Publ., Batavia, IL.

Ruter, J.M. 1992. Influence of source, rate, and method of applicating [sic] controlled release fertilizer on nutrient release and growth of 'Savannah' holly. Fert. Res. 32:101-106.

Scheiber, S.M. and R.C. Beeson. 2006. Petunia growth and maintenance in the landscape as influenced by alternative irrigation strategies. HortScience 41:235-238.

Warncke, D.D. 1986. Analyzing greenhouse growth media by the saturation extraction method. HortScience 21:223-225.

Wiberg, A., R. Koenig, and T. CernyKoenig. 2005. Variability in the physical and chemical properties of retail potting media. HortTechnology 15:752-757.

Wiberg, A., R. Koenig, and T. Cerny-Koenig. 2006. Variability in plant growth in retail potting media. HortTechnology 16:7-12.

Wright, R.D. 1986. The pour through nutrient extraction procedure. HortScience 21:227-229.

Yeager, T.H., D.C. Fare, J. Lea-Cox, J. Ruter, T.E. Bilderback, C.H. Gilliam, A.X. Niemiera, S.L. Warren, T.E. Whitwell, R.D. Wright, and K.M. Tilt. 2007. Best management practices: Guide for producing container-grown plants. 2nd ed. Southern Nurserymen's Assn., Marietta, GA. 